\title{
Use of bundle of His potentials to assess changes in atrioventricular conduction produced by a series of beta-adrenergic blocking agents
}

\author{
Charles S. Smithen ${ }^{1}$, Raphael Balcon ${ }^{2}$, and Edgar Sowton ${ }^{3}$ \\ From the Institute of Cardiology and National Heart Hospital, London W.I
}

$\checkmark$

Changes in atrioventricular conduction produced by propranolol, practolol, and dextropropranolol were studied in 10 patients using the technique of recording His bundle potentials. Increasing the heart rate alone using atrial pacing resulted in a progressive and significant increase in the $P$-His interval, representing atrial and atrioventricular nodal conduction, but no change in the His-S interval, representing total intraventricular conduction. Propranolol significantly increased the $P$-His interval by approximately Io per cent with a dose of 0.02 $\mathrm{mg} / \mathrm{kg}$ and by $\mathrm{I} 7 \mathrm{per}$ cent with a dose of $0.05 \mathrm{mg} / \mathrm{kg}$, with no effect on His-S interval. Dextropropranolol significantly increased atrioventricular nodal conduction by 6 per cent with a dose of $0.2 \mathrm{mg} / \mathrm{kg}$ and had no effect on intraventricular conduction. Practolol produced no significant prolongation in either interval in any of the doses given.

Beta-adrenergic blocking drugs are being used increasingly in the treatment of cardiac dysrhythmias. One of the advantages of some of these preparations has been their ability to slow the ventricular response to atrial fibrillation. It has been possible to separate conduction in the atrioventricular node from total intraventricular conduction since Scherlag $e t$ al. (1969) introduced the technique of recording His bundle potentials in man. It was the purpose of this study to determine the effect of certain beta-adrenergic blocking agents on atrioventricular conduction using bundle of His recordings. The technique of atrial pacing was used to control the heart rate to exclude changes due to slowing of the heart "which usually occurs with these agents, and thus permit separation of this action from effects on atrioventricular conduction. We report here our findings with three of these drugs, propranolol, dextro-propranolol, and practolol.

\section{- Material and methods}

Ten patients with ischaemic heart disease were studied during a routine atrial pacing investigation which formed part of their evaluation for possible

Received 7 April 197 I.

${ }^{1}$ Present addresses: Cornell University, Medical School, New York, U.S.A.

${ }^{2}$ London Chest Hospital, Bonner Road, London E.2.

${ }^{3}$ Guy's Hospital, St Thomas' Street, London S.E.r. revascularization surgery (Balcon, Maloy, and Sowton, 1968). All were in sinus rhythm and had no evidence of other forms of heart disease or cardiac failure. The pertinent clinical data are summarized in Table 1 . There were 8 men and 2 women ranging in age from $4 \mathrm{I}$ to 59 years. None was taking digitalis or a beta-blocking preparation. The diagnosis of ischaemic heart disease was based on a typical history of angina and an abnormal electrocardiogram at rest or on exercise in all patients. Four patients had previous myocardial infarctions and the coronary angiogram was abnormal in 3 other patients.

The patients were fasted but were not premedicated. They were studied in the supine position at rest. In order to record the His bundle potential, a bipolar electrode catheter was introduced percutaneously into the right femoral vein, and under fluoroscopic control positioned across the tricuspid valve as shown in Fig. I. The proximal terminals of the electrode catheter were attached to an electrocardiogram amplifier and used either as a unipolar or bipolar system. The position of the catheter was adjusted slightly until a sharp biphasic deflection appeared between the $P$ wave and the QRS complex. Simultaneous records were made of the intracardiac electrogram and standard lead II of the electrocardiogram on a Sanborn Direct Writer recorder at a paper speed of $100 \mathrm{~mm} / \mathrm{sec}$. A Zucker bipolar electrode catheter was introduced through an arm vein, advanced to the junction of the right atrium and superior vena cava, and used to pace the right atrium with an external battery powered pacemaker. A diagrammatic representation of the 
TABLE I Clinical data in 10 patients with ischaemic heart disease

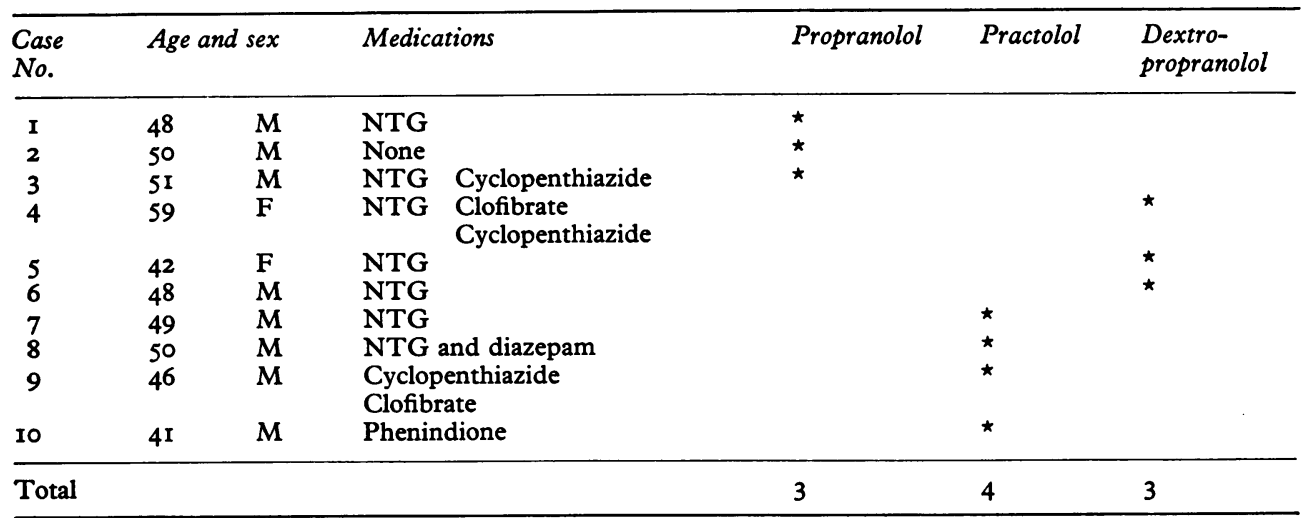

NTG $=$ Nitroglycerin.

FI G. I X-ray showing position of catheter for recording His bundle potentials. The catheter is in the middle of the tricuspid valve area at the base of the atrial septum. The other catheter is situated at the junction of the superior vena cava and right atrium and is used for atrial pacing.

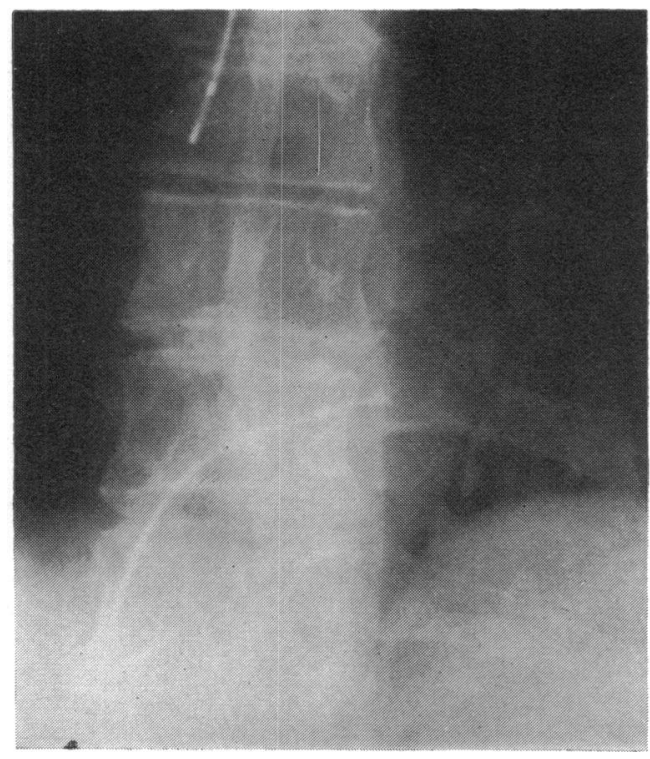

FIG. 2 Diagrammatic representation of measurements made and their relation to the conducting system.

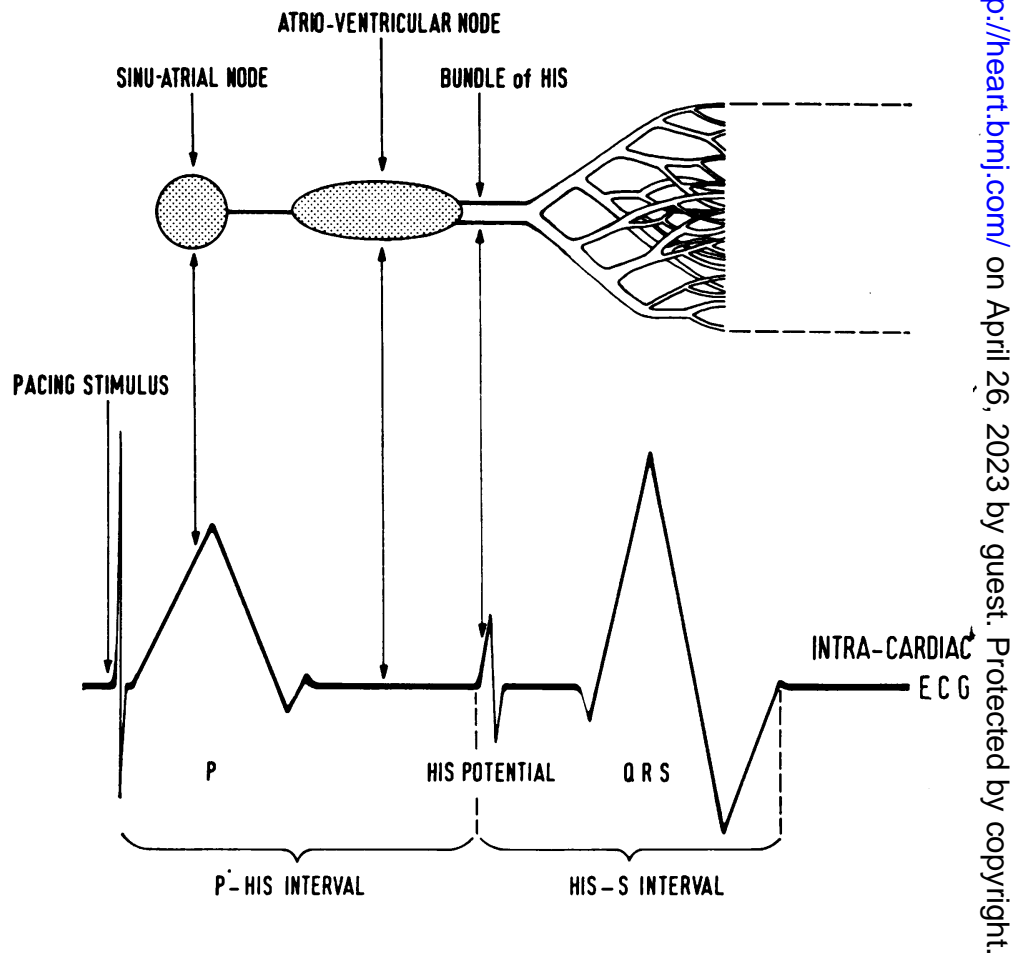


measurements made and their relation to the conducting system is shown in Fig. 2. The P-His interval represents conduction through the atrium and atrioventricular node and the His-S interval prepresents total intraventricular conduction. In this way it was possible to separate effects on the atrioventricular node from the remainder of the conduction system.

Fig. 3 shows an actual recording. The pacing stimulus is followed by the $P$ wave, the bundle of His potential, and finally the QRS complex. The $\mathrm{P}-\mathrm{His}$ interval was measured from the beginning of the pacing stimulus to the beginning of the His potential. The His-S interval was measured from the beginning of the His potential on the intracardiac electrogram to the end of the QRS complex in lead II. The His-Q interval was measured from the beginning of the His potential on the intracardiac electrogram to the beginning of the

QRS in lead II. The mean values from 5 complexes were calculated. In this record the $\mathrm{P}-\mathrm{His}$ interval was ro5 $\mathrm{msec}$ and the His-S interval was I40 msec.

Control measurements were made at pacing rates of $90,100,110$, and 120 beats $/ \mathrm{min}$. After ro minutes the drug was administered into the right atrium at doses within the known therapeutic

- range and measurements repeated at the same pacing rates after a further 5 minutes. Propranolol was given to 3 patients in doses of 0.02 and 0.05 $\mathrm{mg} / \mathrm{kg}$, dextro-propranolol to 3 patients in doses of $0.02,0.05$, and $0.20 \mathrm{mg} / \mathrm{kg}$, and practolol to 4 patients in doses of $0.02,0.05$, and $0.20 \mathrm{mg} / \mathrm{kg}$.

Comparisons of the variables were then made before and after the drugs at the same heart rates.

- Statistical analysis was made by Student's paired ' $t$ ' test.

\section{Results}

The results of all measurements made are shown in Table 2.

Fig. 4 shows the effect of the atrial pacing procedure alone on atrioventricular conduction in the ro patients. In the left hand panel the $\mathbf{P}$-His interval is plotted against the pacing rate. There was a progressive and significant increase with each pacing incre-

- ment, the mean $\mathrm{P}$-His interval being I $53 \mathrm{msec}$ at 90 beats $/ \mathrm{min}, 166 \mathrm{msec}$ at 100 beats $/ \mathrm{min}$, I $80 \mathrm{msec}$ at I IO beats $/ \mathrm{min}$, and $198 \mathrm{msec}$ at 120 beats $/ \mathrm{min}$. In the right-hand panel the His-S interval was plotted similarly. As the pacing rate was increased there was no significant change in the His-S y interval.

The effect of propranolol on atrioventricular conduction is shown in Fig. 5. The data shown are the mean values for the 3 patients given

- the drug. In all cases the P-His interval was prolonged progressively with increasing dosage at each heart rate. This increase in the P-His interval was significant at the $0 \cdot \mathbf{I}$ per cent level for the $0.02 \mathrm{mg} / \mathrm{kg}$ dose and at

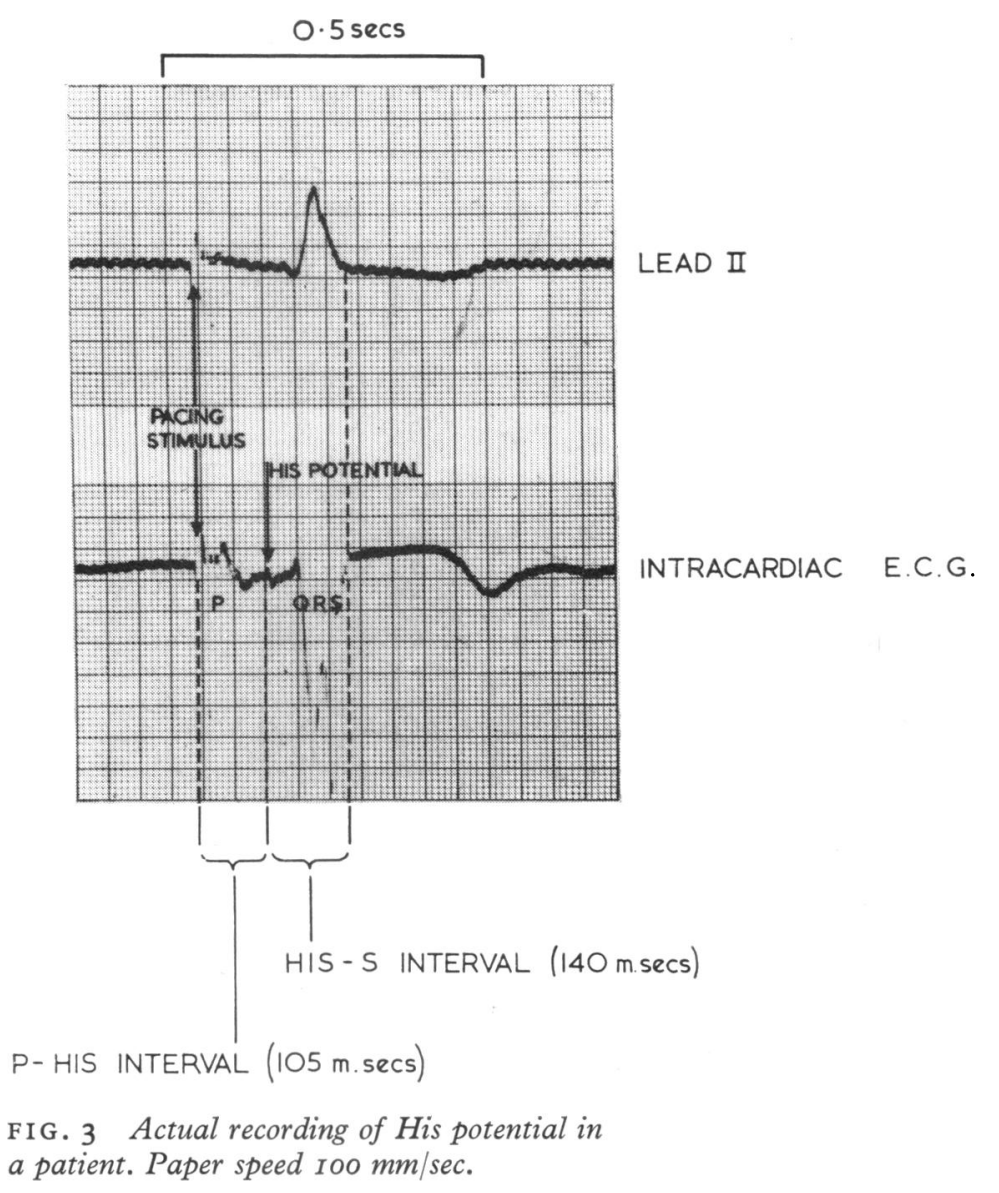

FIG. 4 Effect of atrial pacing on atrioventricular conduction.

EFFECT Of PACING On ATRIO-VENTRICULAR CONOUCTION

(10 patients )
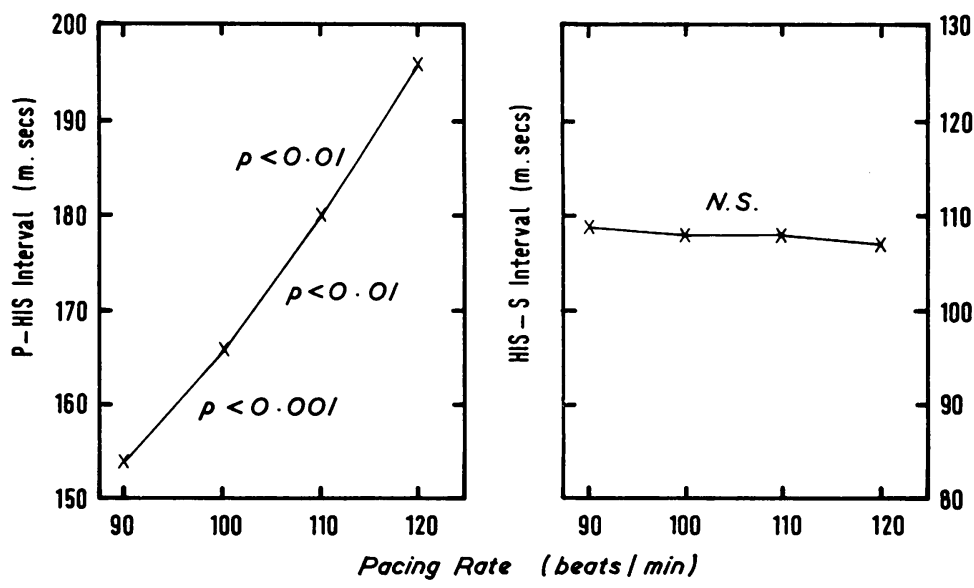
TABLE 2 Measurements of atrioventricular conduction in 10 patients before and after drug administration

\begin{tabular}{|c|c|c|c|c|c|c|c|c|c|c|c|c|c|c|c|c|c|}
\hline \multirow[t]{2}{*}{$\begin{array}{l}\text { Case } \\
\text { No. }\end{array}$} & \multirow[b]{2}{*}{ Heart rate } & \multicolumn{4}{|c|}{$\begin{array}{l}\text { P-His interval } \\
(\mathrm{msec})\end{array}$} & \multicolumn{4}{|c|}{$\begin{array}{l}\text { His-Q interval } \\
(\mathrm{msec})\end{array}$} & \multicolumn{4}{|c|}{$\begin{array}{l}\text { His-S interval } \\
(m s e c)\end{array}$} & \multicolumn{4}{|c|}{$\begin{array}{l}\text { QRS interval } \\
\text { (msec) }\end{array}$} \\
\hline & & 90 & 100 & IIO & 120 & 90 & 100 & IIO & 120 & 90 & 100 & IIO & 120 & 90 & 100 & IIO & 120 \\
\hline \multirow[t]{2}{*}{$\mathbf{I}$} & Control & II 8 & 128 & 131 & 144 & 51 & 50 & 50 & $5 \mathrm{I}$ & 120 & 120 & 122 & I2I & 69 & 70 & 72 & 70 \\
\hline & Propranolol $(0.02 \mathrm{mg} / \mathrm{kg})$ & 133 & 148 & 162 & 165 & - & - & - & - & - & - & - & - & - & - & - & - \\
\hline \multirow[t]{3}{*}{2} & Control & 116 & 115 & 129 & 134 & 46 & 45 & 47 & 42 & 104 & 105 & 105 & 102 & 58 & 60 & 58 & 60 \\
\hline & Pronranolol $0.02 \mathrm{mg} / \mathrm{kg}$ & 126 & 137 & 137 & 146 & 46 & 45 & 48 & 48 & IOI & 100 & 100 & 100 & 55 & 55 & 52 & 52 \\
\hline & Propranolol $\left\{\begin{array}{l}0.05 \mathrm{mg} / \mathrm{kg}\end{array}\right.$ & 118 & 131 & 140 & 140 & 47 & 48 & 47 & 50 & 102 & 99 & 100 & 98 & 55 & 51 & 53 & 48 \\
\hline \multirow[t]{3}{*}{3} & Control & 202 & 208 & 213 & 223 & 29 & 30 & 29 & 30 & I2I & 120 & I2I & 118 & 92 & 90 & 92 & 88 \\
\hline & Propranolol $\{0.02 \mathrm{mg} / \mathrm{kg}$ & 210 & 215 & 235 & 240 & 30 & $3 I$ & 30 & 30 & 126 & 123 & 123 & 125 & 96 & 92 & 93 & 95 \\
\hline & Propranolol $\{0.05 \mathrm{mg} / \mathrm{kg}$ & 215 & 225 & 237 & 247 & 30 & 30 & 30 & 30 & 125 & 123 & 121 & 122 & 95 & 93 & 91 & 92 \\
\hline \multirow[t]{4}{*}{4} & Control & 186 & 202 & 212 & 216 & 32 & 35 & 30 & 33 & 83 & 84 & 79 & 81 & $5 I$ & 49 & 49 & 48 \\
\hline & $(0.02 \mathrm{mg} / \mathrm{kg}$ & 186 & 201 & 211 & 220 & 34 & 35 & 35 & 33 & 82 & 82 & 85 & 83 & 49 & 47 & 50 & 50 \\
\hline & Dextro-propranolol $0.05 \mathrm{mg} / \mathrm{kg}$ & 183 & 204 & 214 & 223 & 33 & 32 & 32 & 35 & 83 & 82 & 80 & 83 & 50 & 50 & 48 & $48^{2}$ \\
\hline & $0.2 \mathrm{mg} / \mathrm{kg}$ & 192 & 204 & 218 & 226 & 35 & 35 & 35 & 34 & 84 & 85 & 80 & 82 & 49 & 50 & 46 & 48 \\
\hline \multirow[t]{4}{*}{5} & Control & IOI & IIO & 123 & 140 & 40 & 40 & 42 & 40 & $8 I$ & 80 & 82 & 83 & $4 \mathrm{I}$ & 40 & 38 & 43 \\
\hline & $0.02 \mathrm{mg} / \mathrm{kg}$ & II2 & 124 & 145 & - & 38 & 38 & 38 & - & 80 & 75 & 75 & - & 4I & 38 & 38 & - \\
\hline & Dextro-propranolol $0.05 \mathrm{mg} / \mathrm{kg}$ & 109 & 125 & 145 & - & 38 & 38 & 35 & - & 79 & 80 & 78 & - & $4 \mathrm{I}$ & 42 & 43 & - \\
\hline & $(0.2 \mathrm{mg} / \mathrm{kg}$ & 123 & 132 & 148 & 175 & 42 & - & 40 & 35 & 81 & 80 & 83 & 78 & 39 & - & 43 & 43 \\
\hline \multirow[t]{4}{*}{6} & Control & 158 & 183 & 214 & 262 & 38 & 33 & 35 & - & 125 & I28 & 120 & 125 & 90 & 95 & 85 & 一 \\
\hline & $\int 0.02 \mathrm{mg} / \mathrm{kg}$ & 152 & 170 & 234 & 264 & 40 & 38 & 38 & 39 & 128 & 130 & 128 & 133 & 88 & 92 & 90 & 94 \\
\hline & Dextro-propranolol $0.05 \mathrm{mg} / \mathrm{kg}$ & 153 & 174 & 233 & 260 & 40 & 40 & 35 & 40 & 135 & I30 & 135 & 130 & 95 & 90 & 100 & 90 \\
\hline & $(0.2 \mathrm{mg} / \mathrm{kg}$ & 150 & 175 & 238 & 一 & 35 & 35 & 40 & - & 130 & 130 & 130 & 一 & 95 & 95 & 90 & 一 \\
\hline \multirow[t]{3}{*}{7} & Control & 190 & 194 & 200 & 215 & 65 & 64 & 63 & 65 & 133 & 129 & 128 & 120 & 68 & 64 & 65 & 55 \\
\hline & Practolol $\{0.05 \mathrm{mg} / \mathrm{kg}$ & 190 & I98 & 209 & 218 & $6 I$ & 60 & 64 & 62 & 126 & 125 & 125 & 130 & 65 & 65 & 60 & 68 \\
\hline & Practolol $\{0.2 \mathrm{mg} / \mathrm{kg}$ & 190 & 199 & 205 & 208 & 55 & 61 & 67 & 60 & II5 & 120 & 120 & 125 & 60 & 58 & 53 & 65 \\
\hline \multirow[t]{4}{*}{8} & Control & 137 & 159 & 180 & 186 & 43 & 44 & 43 & 45 & 90 & 94 & 95 & 91 & 47 & 50 & 52 & 50 \\
\hline & $(0.02 \mathrm{mg} / \mathrm{kg}$ & 127 & I36 & 182 & I8I & - & - & - & - & - & - & - & - & - & - & - & - \\
\hline & Practolol $0.05 \mathrm{mg} / \mathrm{kg}$ & I2I & I52 & 166 & 175 & 44 & 47 & 46 & 43 & 94 & 95 & 95 & 93 & 50 & 48 & 49 & 50 \\
\hline & $0.2 \mathrm{mg} / \mathrm{kg}$ & II 8 & I5I & 170 & 173 & 42 & 44 & 46 & 43 & 92 & 92 & 91 & 90 & 50 & 48 & 45 & 48 \\
\hline \multirow[t]{4}{*}{9} & Control & 143 & 163 & I 88 & 223 & 62 & 60 & 65 & 65 & 107 & 102 & 105 & 105 & 45 & 42 & 40 & 40 \\
\hline & $(0.02 \mathrm{mg} / \mathrm{kg}$ & 176 & 190 & 201 & 210 & 60 & 6I & 64 & 58 & 106 & 106 & 106 & IOI & 46 & 45 & 43 & 43 \\
\hline & Practolol $0.05 \mathrm{mg} / \mathrm{kg}$ & 170 & I77 & 207 & 216 & 59 & 55 & 58 & $6 I$ & 102 & 103 & 102 & 108 & 42 & 48 & 43 & 46 \\
\hline & $0.2 \mathrm{mg} / \mathrm{kg}$ & 190 & 202 & 213 & 225 & 63 & 65 & 63 & 53 & 103 & 117 & 107 & 100 & 40 & 52 & 43 & 48 \\
\hline \multirow[t]{3}{*}{ IO } & Control & 132 & 146 & I58 & 173 & 35 & 38 & 42 & 38 & 122 & 122 & 123 & 123 & 87 & 84 & 83 & 83 \\
\hline & Practolol $\{0.05 \mathrm{mg} / \mathrm{kg}$ & 136 & 151 & 160 & 178 & 36 & 38 & 36 & 35 & 127 & 125 & 124 & 120 & 90 & 87 & 88 & 85 \\
\hline & Fractolo1 $\{0.2 \mathrm{mg} / \mathrm{kg}$ & I42 & I5I & 165 & I 78 & 38 & 36 & 35 & 34 & 126 & 121 & 125 & 120 & 88 & 85 & 90 & 85 \\
\hline
\end{tabular}

the I per cent level for the higher dose when the data at the four heart rates were pooled. The difference between the two doses was also significant at the I per cent level. No significant change in the His-S interval was shown after propranolol.

The dextroisomer of propranolol had no significant effect on atrioventricular conduction at the same dosage levels as propranolol (Fig. 6). However, in the larger dose of $0.02 \mathrm{mg} / \mathrm{kg}$ the $\mathrm{P}-\mathrm{His}$ interval was significantly prolonged when compared to the control values $(\mathbf{P}<0.01)$. As with propranolol, the dextroisomer had no effect on the His-S interval.

The results with practolol on atrioventricu- lar conduction are shown in Fig. 7. No significant effect could be shown on either the $\mathrm{P}-\mathrm{His}$ or the His-S intervals at the doses used.

The observed changes were therefore only on the P-His interval representing atrial and atrioventricular nodal conduction. The histogram in Fig. 8 compares the effects of the 3 drugs on this interval. Propranolol significantly increased the $\mathrm{P}$-His interval by approximately to per cent with a dose of $0.02 \mathrm{mg} / \mathrm{kg}$ and by 17 per cent with a dose of $0.05 \mathrm{mg} / \mathrm{kg}$. This drug was not given in the higher dose because of possible side effects. Dextro-propranolol increased conduction only slightly in the lower doses but with a dose of 


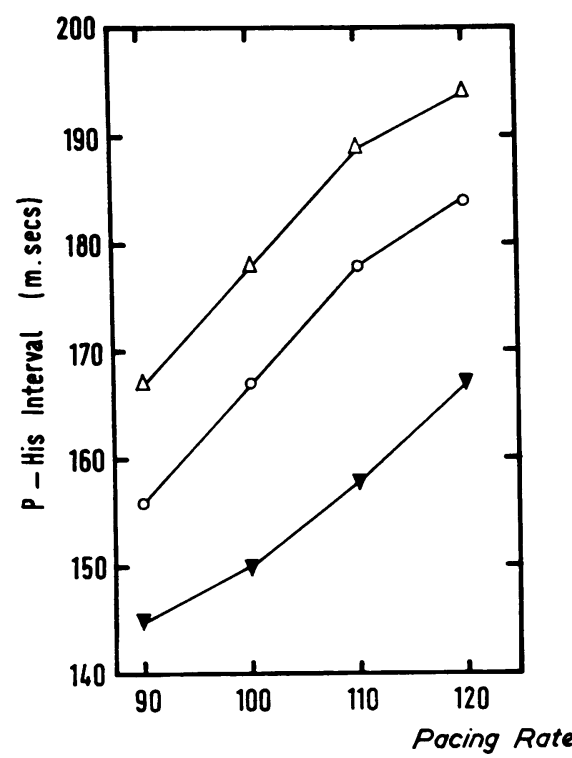

$\nabla$ control

$0.02 \mathrm{mg} / \mathrm{kg}$

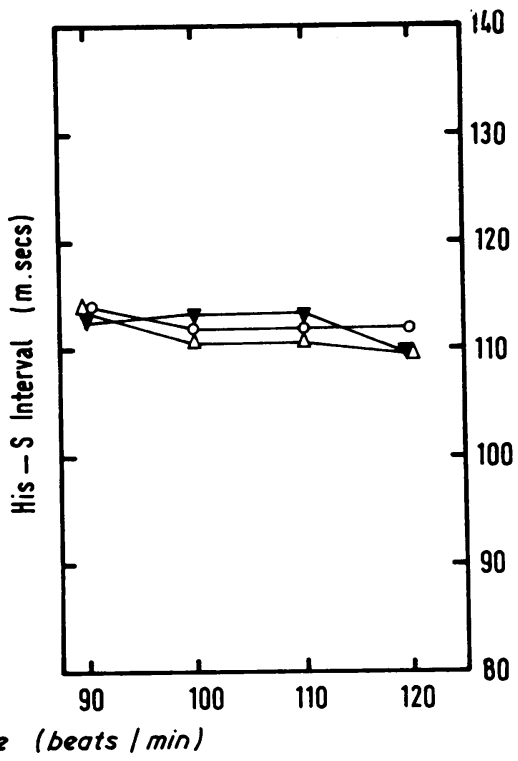

$\Delta 0.05 \mathrm{mg} / \mathrm{kg}$

FIG. 5 Effect of propranolol on atrioventricular conduction.

$0.02 \mathrm{mg} / \mathrm{kg}$ there was a significant prolongation of the P-His interval by 6 per cent. Practolol produced no significant prolongation in any of the doses given.

\section{Discussion}

The value of His bundle recordings in man has recently been shown by a number of investigators (Damato and Lau, 1970; Narula - et al., 1970b). The position of the monitoring electrode should be stable at the base of the atrial septum in the middle of the tricuspid valve area, and the His potential appears as a

- rapid biphasic or triphasic deflection between the $P$ wave and the $Q R S$ complex; it should not vary significantly either in configuration or distance from the $P$ wave in several successive cardiac cycles. The configuration and relations of the bundle of His deflection have been validated by direct placement of

1 the electrode on the His bundle during cardiotomy under experimental conditions (Alanís, González, and López, I958; Hoffman et al., 1960). We have found the recording of

"the His potential to be a simple and safe procedure, and were able to record it quickly in all ro patients studied.

It has been previously shown that increasing the heart rate by atrial pacing results in a
FIG. 6 Effect of dextro-propranolol on atrioventricular conduction.

EFFeCt of dextro-propranolol on atrio-Ventricular conduction (3 Patients)

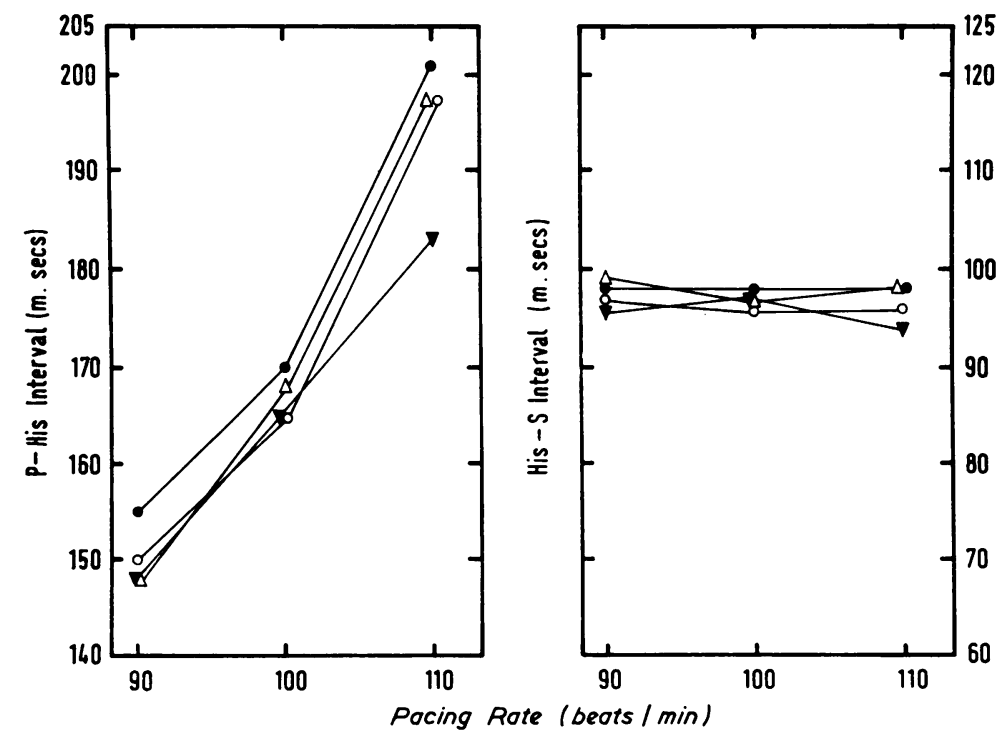
$\checkmark$ control
$\Delta 0.05 \mathrm{mg} / \mathrm{kg}$
$\circ 0.02 \mathrm{mg} / \mathrm{kg}$
- $0.20 \mathrm{mg} / \mathrm{kg}$ 
progressive prolongation of the PR interval (Balcon and Sowton, 1970). In this study we have shown that this prolongation is due entirely to an increase of the P-His interval, the His-S interval remaining constant. Scherlag et al. (1969) and Narula et al. (1970a) reported similar findings.

Racemic propranolol is known to affect the rate of rise of the action-potential, (a 'membrane effect') in addition to blocking the betaadrenergic effects of adrenaline. While the dextroisomer possesses only the membrane effect in normal clinical doses (Barrett, 1969). In doses within the known therapeutic range the racemic drug produced a significant increase in atrioventricular conduction of up to 7 per cent without affecting intraventricular conduction. This effect was anticipated since it has previously been shown that betaadrenergic stimulation with isoprenaline conspicuously shortened the $\mathrm{P}$-His interval without changing the His-S interval (Damato et al., 1969). Since dextro-propranolol produced a much smaller but still statistically significant change in $\mathrm{P}$-His interval, the racemic mixture appears to act by both beta blockade and by membrane action.

Assuming a similar level of sympathomimetic activity in all patients, practolol, a beta-blocker without significant membrane action in these doses, would be expected to have an effect somewhere between the other two in comparable doses, since the molecular weight of the three drugs is similar. However, its observed effect was negligible. Part of this discrepancy might be explained by the intrinsic sympathomimetic action of practolol which tends to counteract the slowing of conduction. Another possibility is that the dose of practolol used was not sufficient to produce any effect on atrioventricular conduction, and that a higher dose would have resulted in prolongation of the $\mathrm{P}-\mathrm{His}$ interval. Finally, this difference may have been due to varying rates of diffusion of the drugs to the effector site in the atrioventricular node. This finding emphasizes the danger of assuming uniformity of action in intact man of different beta-adrenergic blocking agents. The effect on one variable such as conduction through the atrioventricular node cannot necessarily be predicted by knowledge of the action on any other variable that forms part of the betaadrenergic system. Gibson, Hoy, and Sowton

FIG. 8 Effect of propranolol, dextropropranolol, and practolol on the $\mathrm{P}-\mathrm{His}$ interval.
EFFECT of PRACTOLOL on ATRIO-VENTRICULAR CONOUCTION

(4 patients)
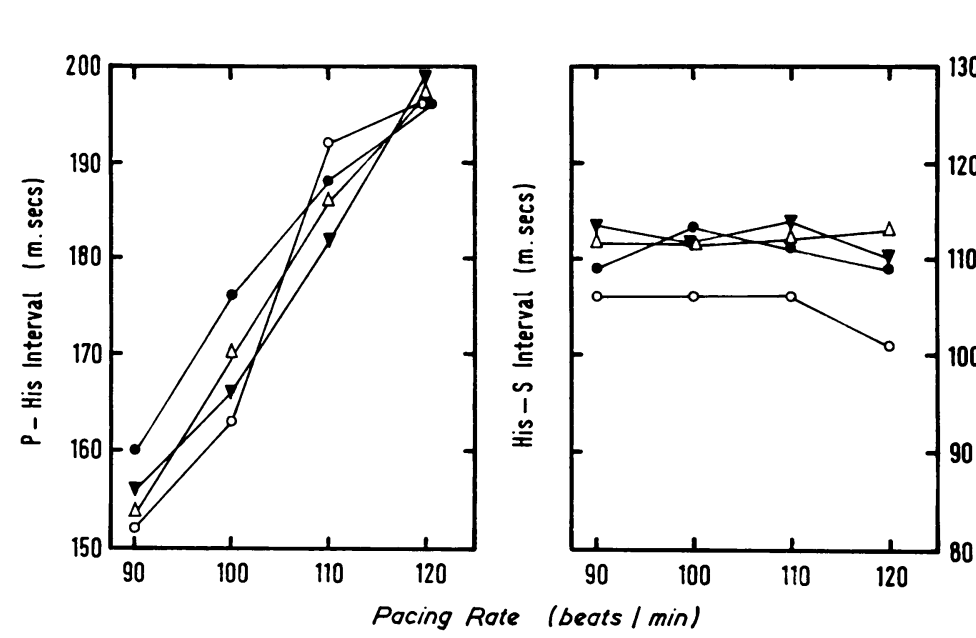

v control

$\Delta 0.05 \mathrm{mg} / \mathrm{kg}$

$\circ 0.02 \mathrm{mg} / \mathrm{kg}$

- $0.20 \mathrm{mg} / \mathrm{kg}$

FIG. 7 Effect of practolol on atrioventricular conduction.

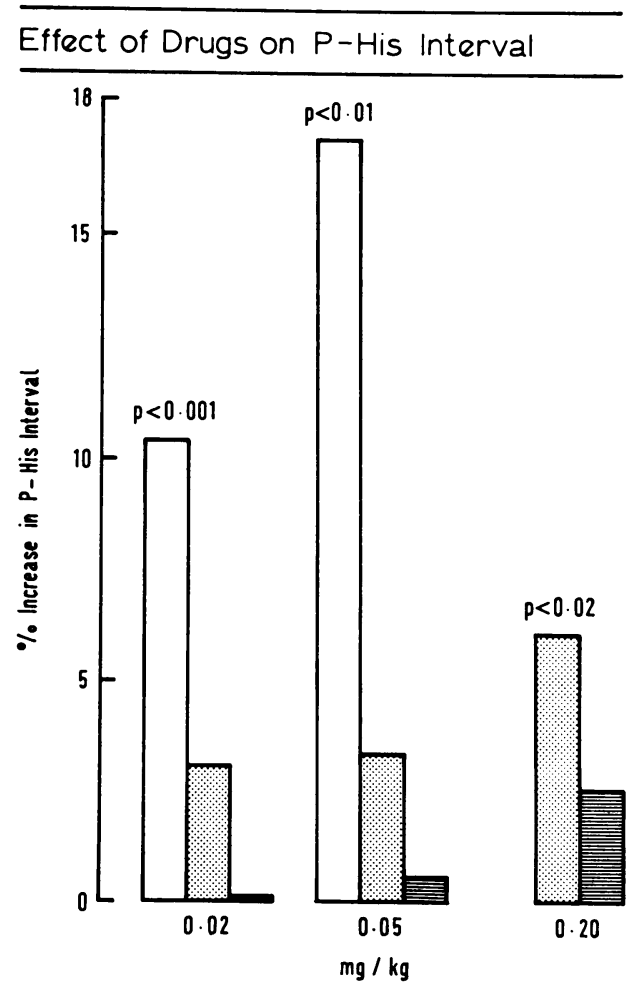

PROPRANOLOL

DEXTRO-PROPRAMOLOL

PRACTOLOL 
(1970) have already shown with various drugs that they have quantitatively different actions with respect to their chronotropic effect compared with their action on ventricular function.

\section{References}

Alanís, J., González, H., and López, E. (1958). The electrical activity of the bundle of His. Fournal of Physiology, 142, 127.

Balcon, R., Maloy, W. C., and Sowton, E. (1968). Clinical use of atrial pacing test in angina pectoris. British Medical fournal, 3, 91 .

Balcon, R., and Sowton, E. (1970). The haemodynamic effects of atrial pacing in patients with ischaemic heart disease. Acta Medica Scandinavica, 188, 119.

Barrett, A. M. (1969). A comparison of the effects of $( \pm)$-propranolol and $(+)$-propranolol in anaesthetized dogs; $\beta$-receptor blocking and haemodynamic action. Fournal of Pharmacy and Pharmacology, 21, 241.

Damato, A. N., and Lau, S. H. (I970). Clinical value of the electrogram of the conduction system. Progress in Cardiovascular Diseases, 13, I19.

Damato, A. N., Lau, S. H., Helfant, R. H., Stein, E., Berkowitz, W. D., and Cohen, S. I. (I969). Study of atrioventricular conduction in man using electrode catheter recordings of His bundle activity. Circulation, 39, 287.

Gibson, D. G., Hoy, J., and Sowton, E. (1970). Comparison of haemodynamic effects of oxprenolol (trasicor), alprenolol (aptin), and sotalol (MJ.1999) in man. In Proceedings of the British Cardiac Society. British Heart fournal, 32, 553.

Hoffman, B. F., Cranefield, P. F., Stuckey, J. H., and Bagdonas, A. A. (1960). Electrical activity during the P-R interval. Circulation Research, 8, 1200.

Narula, O. S., Cohen, L. S., Samet, P., Lister, J. W. Scherlag, B., and Hildner, F. J. (1970a). Localization of A-V conduction defects in man by recording of the His bundle electrogram. American fournal of Cardiology, 25, 228.

Narula, O. S., Scherlag, B. J., Javier, R. P., Hildner, F. J., and Samet, P. (1970b). Analysis of the A-V conduction defect in complete heart block utilizing His bundle electrograms. Circulation, 41, 437.

Scherlag, B. J., Lau, S. H., Helfant, R. H., Berkowitz, W. D., Stein, E., and Damato, A. N. (1969). Catheter technique for recording $\mathrm{His}$ bundle activity in man. Circulation, 39, 13.

Requests for reprints to Dr. E. Sowton, Department of Cardiology, Guy's Hospital, London S.E.r. 